\title{
Bisphenol S Interacts with Catalase and Induces Oxidative Stress in Rat Liver and Renal Cells ${ }^{\dagger}$
}

\author{
Rui Zhang ${ }^{\dagger}$ Rutao Liu, ${ }^{*, \dagger}$ and Wansong Zong ${ }^{\S}$
}

${ }^{\dagger}$ School of Environmental Science and Engineering, Shandong University,

China-America CRC for Environment \& Health, Shandong Province, 27\# Shanda

South Road, Jinan 250100, People's Republic of China

${ }^{\S}$ College of Population, Resources and Environment, Shandong Normal University, 88\# East Wenhua Road, Jinan 250014, People's Republic of China

* (R. L. China). Phone/fax: 86-531-88365489. E-mail: rutaoliu@ sdu.edu.cn. 


\section{Liver}

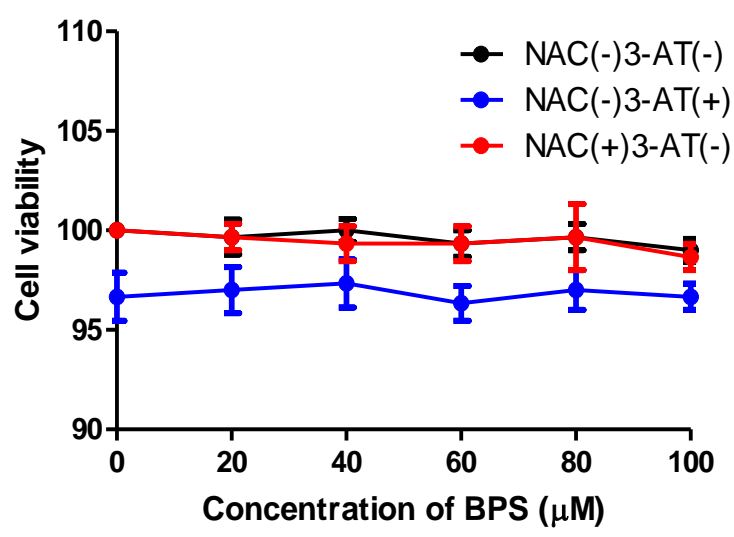

Kidney

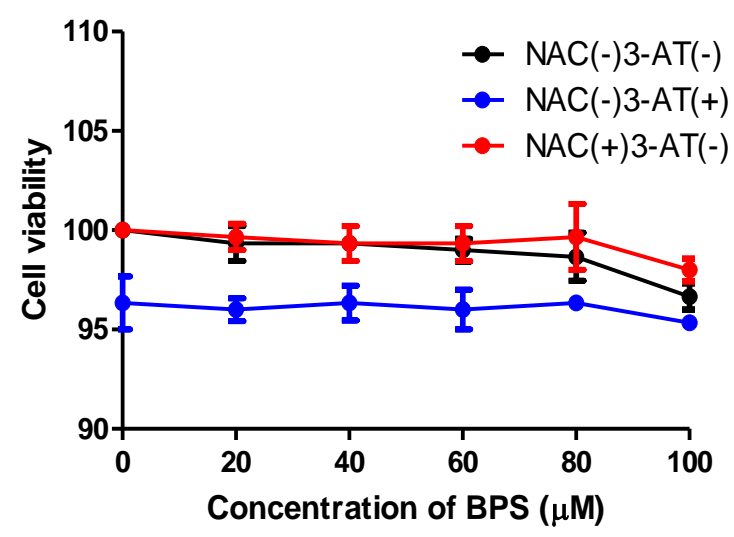

Fig. S1 Cytotoxicity of BPS in the hepatocytes and renal cells after $12 \mathrm{~h}$ exposure to 0-100 $\mu$ M BPS. Cell viability was determined using Muse ${ }^{\mathrm{TM}}$ Count $\&$ Viability Kit on a MUSETM cell analyzer and expressed as percentages of control. The values are presented as the mean \pm SEM of independent experiments $(n=3)$. Cells were exposed to $0,20,40,60,80,100 \mu \mathrm{M}$ BPS for $12 \mathrm{~h}$ and pretreated with or without $0.1 \mathrm{mM}$ NAC or 20mM 3-AT for $1 \mathrm{~h}$ before BPS incubation. 
Liver
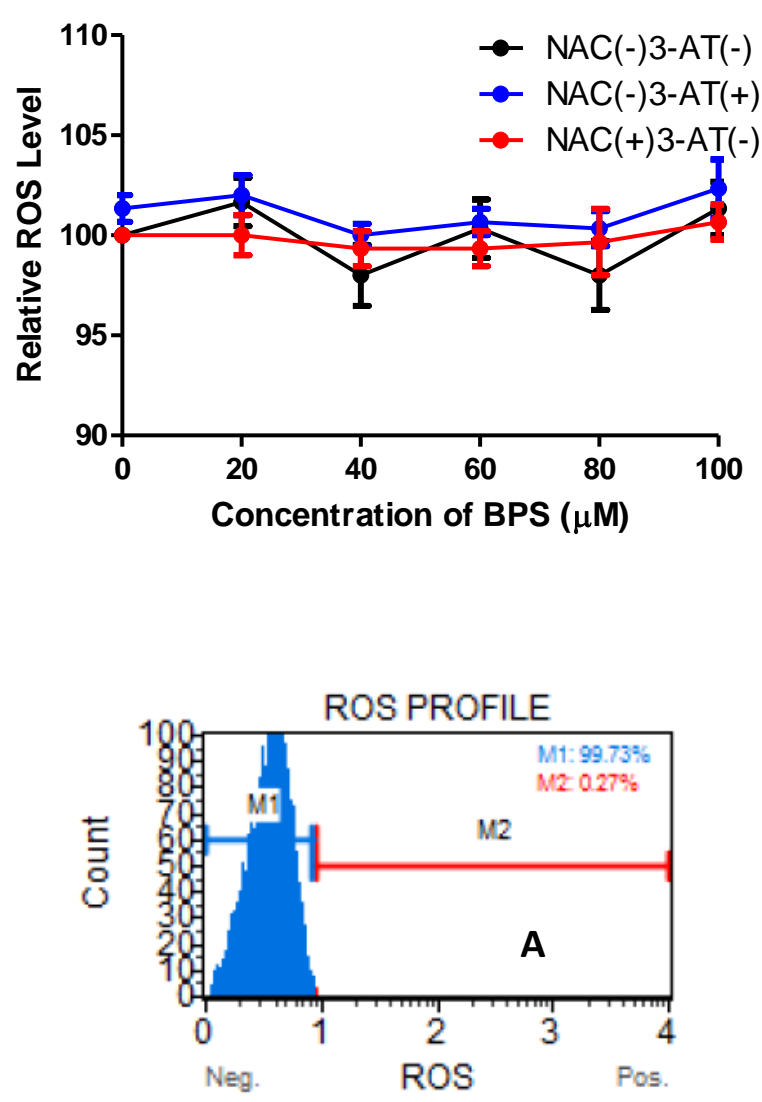

Kidney
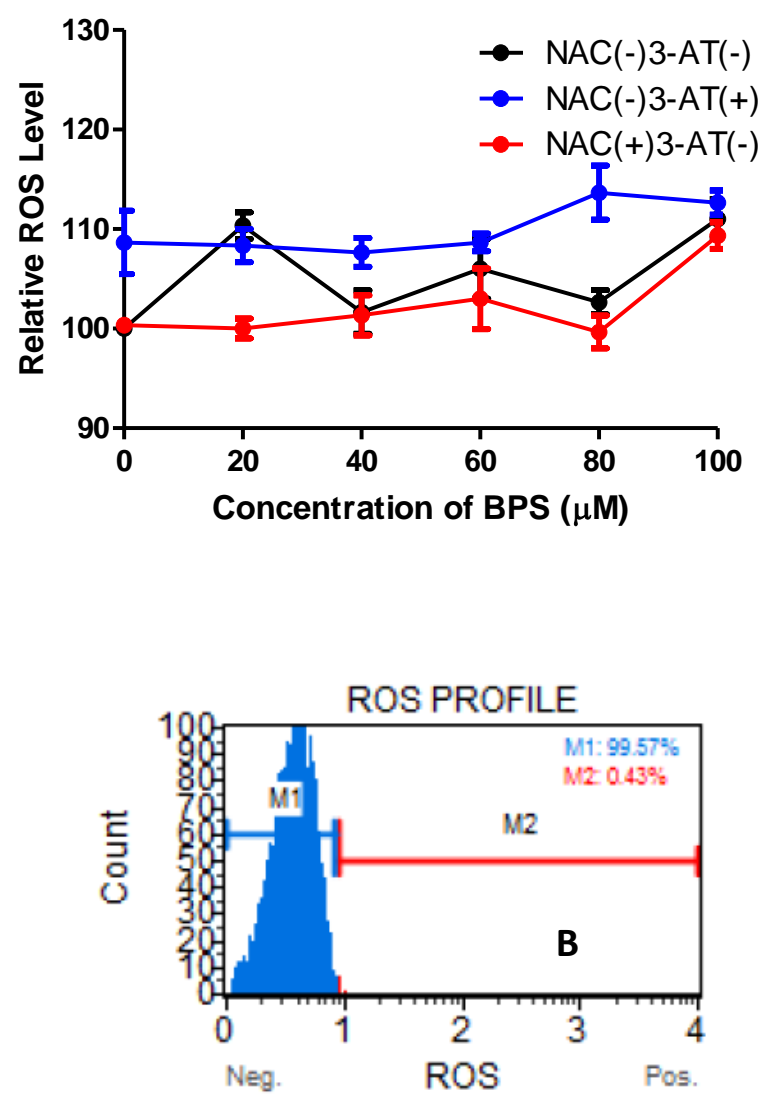

Fig. S2 Relative ROS levels in BPS-treated hepatocytes and renal cells after $12 \mathrm{~h}$, measured by MUSE ${ }^{\mathrm{TM}}$ cell analyzer using Muse ${ }^{\mathrm{TM}}$ oxidative stress Kit. Cells were exposed to $0,20,40,60,80,100 \mu \mathrm{M}$ BPS for $12 \mathrm{~h}$ and pretreated with or without 0.1 $\mathrm{mM}$ NAC or $20 \mathrm{mM} 3$-AT for $1 \mathrm{~h}$ before BPS incubation. Values are means \pm SEM $(\mathrm{n}=3)$. A: ROS level in BPS-treated hepatocytes $\left(\mathrm{C}_{\mathrm{BPS}}=100 \mu \mathrm{M}\right)$; B: ROS level in BPS-treated renal cells $\left(\mathrm{C}_{\mathrm{BPS}}=100 \mu \mathrm{M}\right)$ 

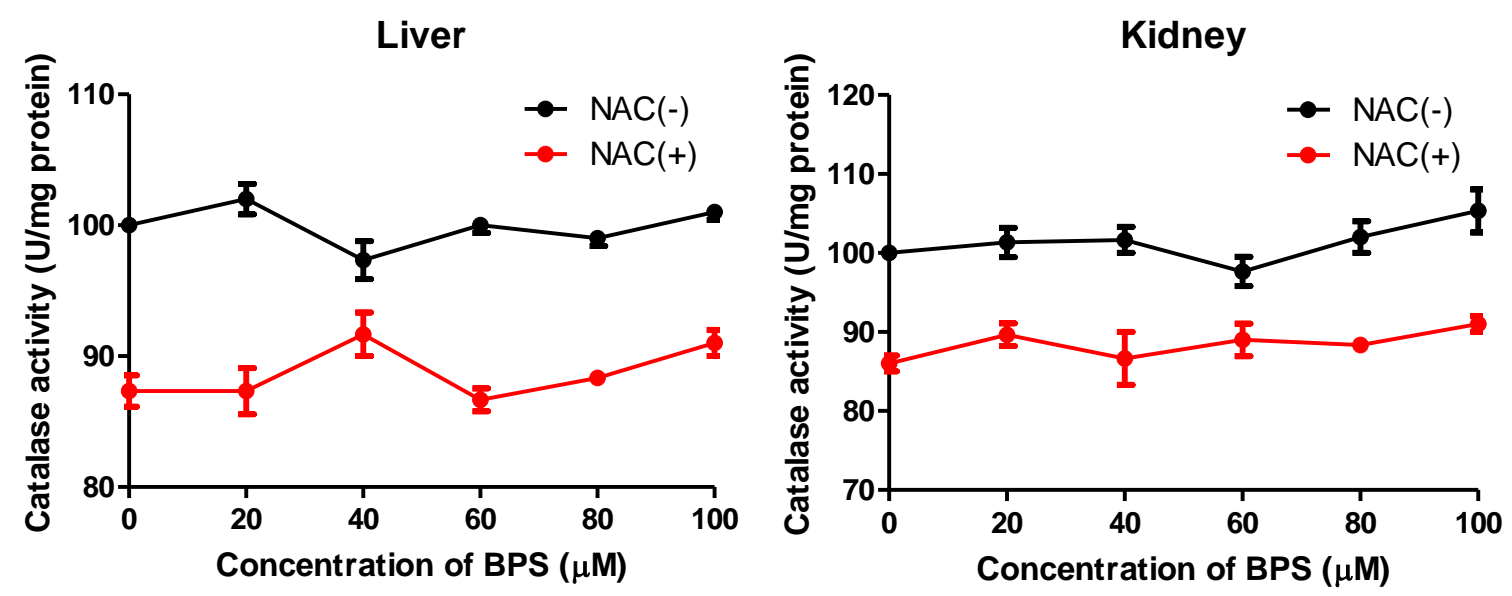

Fig. S3 CAT activity in hepatocytes and renal cells after $12 \mathrm{~h}$ exposure to BPS. Data are expressed as unit for $\mathrm{mg}$ of total proteins (Unit/mg proteins \pm SEM) and compared to each control. Cells were exposed to $0,20,40,60,80,100 \mu \mathrm{M}$ BPS for $12 \mathrm{~h}$ and pretreated with or without $0.1 \mathrm{mM}$ NAC for $1 \mathrm{~h}$ before BPS incubation. 

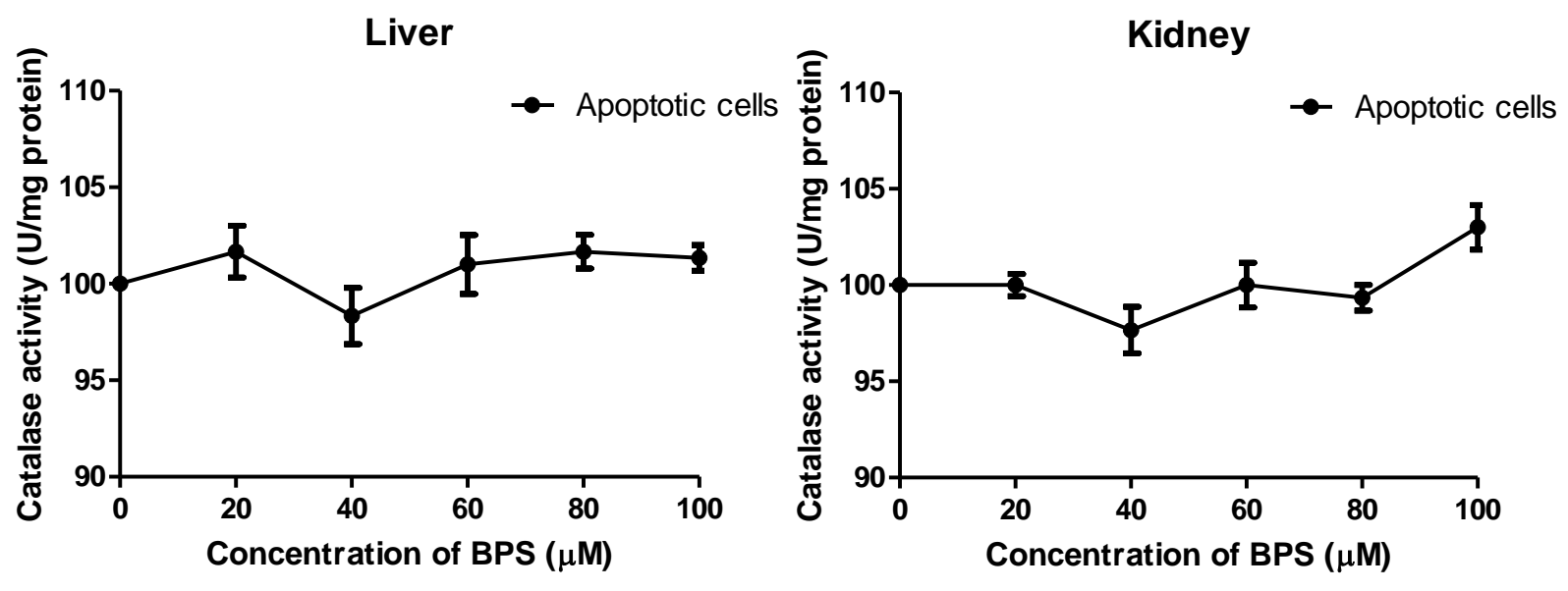

Fig. S4 Percentage of apoptotic cells of hepatocytes and renal cells after $12 \mathrm{~h}$ incubation with BPS. Cells were exposed to 0, 20, 40, 60, 80, $100 \mu \mathrm{M}$ BPS for $12 \mathrm{~h}$. 

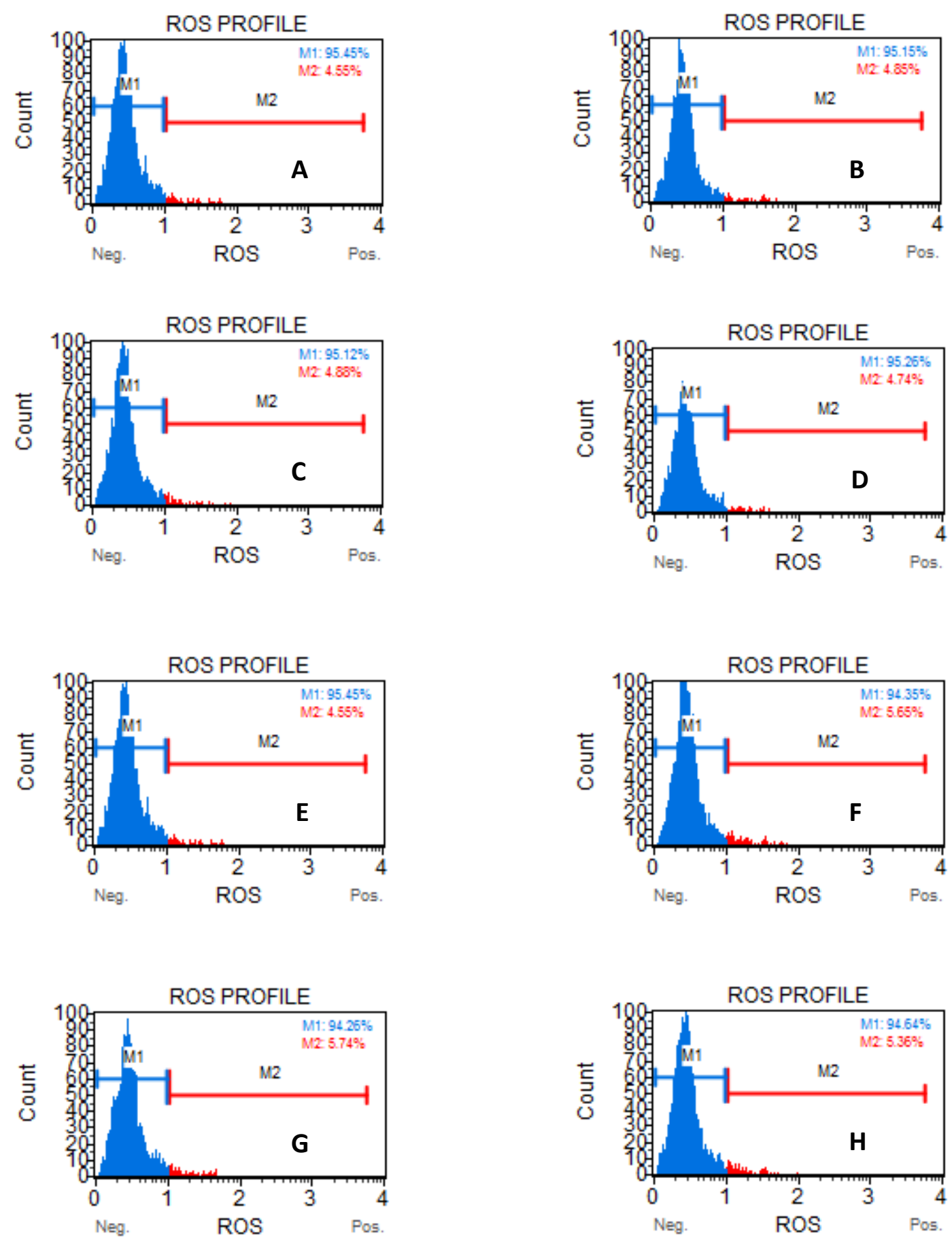

Fig. S5 Representative images of ROS level assay of the hepatocytes.

Condition: (A) blank control (B) $0.1 \mathrm{mM}$ BPS (C) $0.1 \mathrm{mM}$ BPS with 3-AT pretreatment (D) $0.1 \mathrm{mM}$ BPS with NAC pretreatment. (E) blank control (F) $1 \mathrm{mM}$ BPS (G) 1 mM BPS with 3-AT pretreatment (H) $1 \mathrm{mM}$ BPS with NAC pretreatment. 

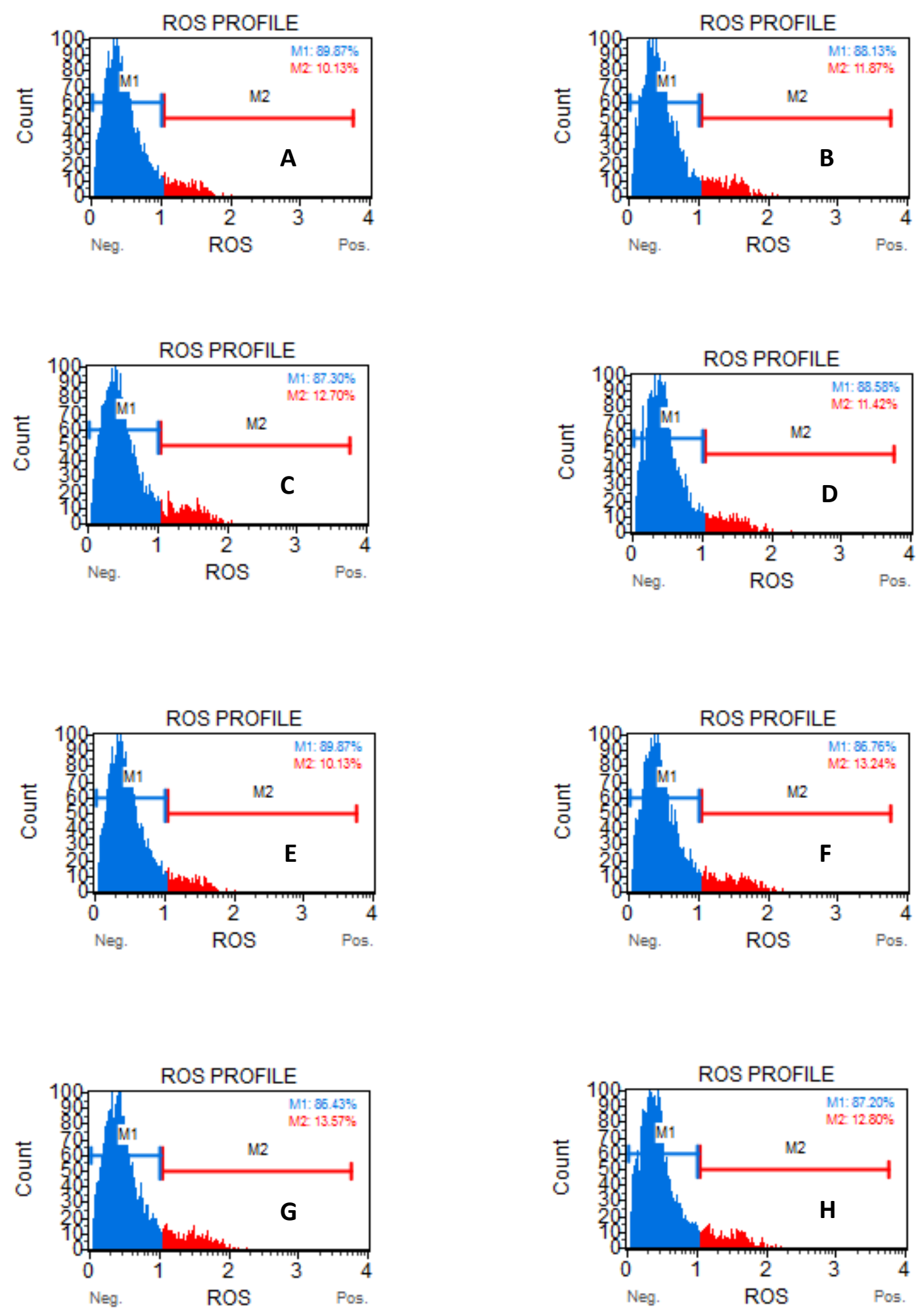

Fig. S6 Representative images of ROS level assay of the renal cells.

Condition: (A) blank control (B) $0.1 \mathrm{mM}$ BPS (C) $0.1 \mathrm{mM}$ BPS with 3-AT pretreatment (D) $0.1 \mathrm{mM}$ BPS with NAC pretreatment. (E) blank control (F) $1 \mathrm{mM}$ BPS (G) 1 mM BPS with 3-AT pretreatment (H) 1 mM BPS with NAC pretreatment. 


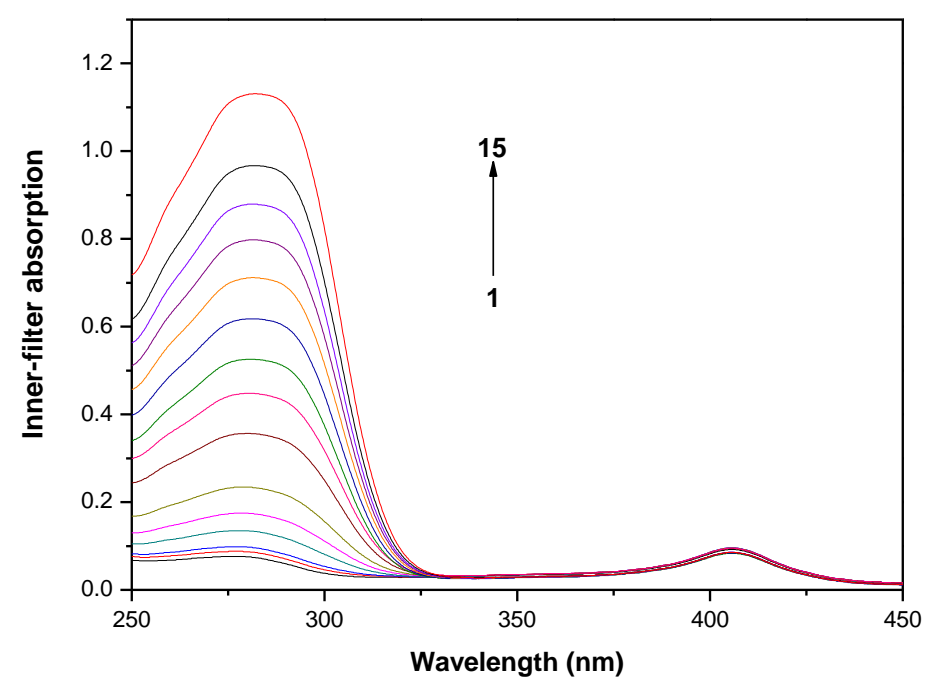

Fig. $\mathbf{S 7}$ The inner-filter effect of BPS-CAT system. Conditions: $\mathrm{C}_{\mathrm{CAT}}: 2 \mu \mathrm{M}, \mathrm{C}_{\mathrm{BPS}}: 0$, $0.001,0.005,0.025,0.05,0.1,0.2,0.3,0.4,0.5,0.6,0.7,0.8,0.9,1 \mathrm{mM}, \mathrm{pH}=7.4, \mathrm{~T}=$ $300 \mathrm{~K}$ 


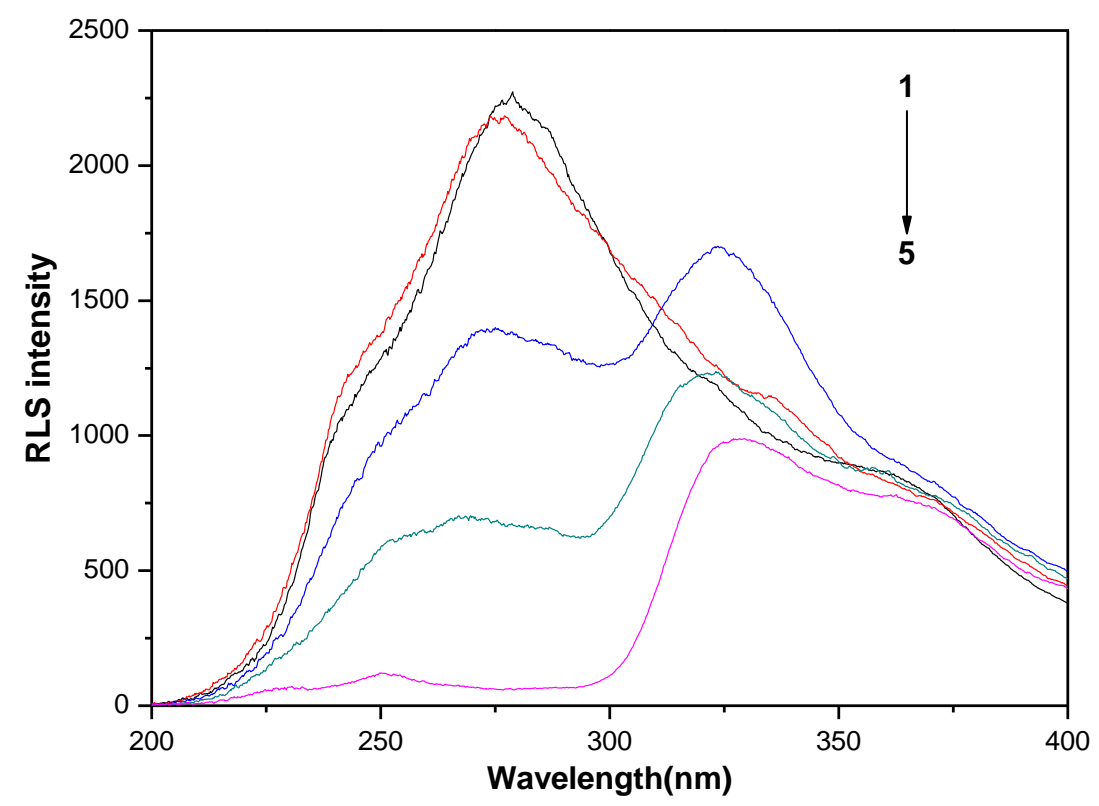

Fig. S8 RLS spectra of BPS-CAT system.

Experimental conditions: $\mathrm{T}=300 \mathrm{~K}, \mathrm{pH}=7.4 ; \mathrm{C}_{\mathrm{CAT}}=2 \mu \mathrm{M}, \mathrm{C}_{\mathrm{BPS}}: 0,0.005,0.025,0.1$, $0.7 \mathrm{mM}$ 
Table S1. Three-dimensional characteristics of CAT and CAT-BPS complex.

\begin{tabular}{ccccc}
\hline & \multicolumn{2}{c}{ peak 1 } & \multicolumn{3}{c}{ peak 2 } \\
\cline { 2 - 5 } BPS & Position & intensity F & $\begin{array}{c}\text { Position } \\
\lambda_{\text {ex }} / \lambda_{\text {em }}(\mathrm{nm} / \mathrm{nm})\end{array}$ & intensity F \\
\hline$\square \mathrm{M})$ & $\lambda_{\mathrm{ex}} / \lambda_{\mathrm{em}}(\mathrm{nm} / \mathrm{nm})$ & & $228 / 336$ & 4297 \\
0 & $278 / 330$ & 2452 & $228 / 338$ & 3895 \\
0.001 & $278 / 330$ & 2028 & $228 / 330$ & 3354 \\
0.005 & $278 / 334$ & 1429 & $228 / 330$ & 1562 \\
0.1 & $278 / 330$ & 360.2 & $228 / 328$ & 375 \\
1 & -- & -- & -- & -- \\
\hline
\end{tabular}


Table S2. Ranked energy of the 14 sites in CAT obtained by docking with BPS

\begin{tabular}{cc}
\hline Site & Energy (kcal mol-1) \\
\hline 1 & -12.3432 \\
2 & -11.6509 \\
3 & -11.1393 \\
4 & -10.9099 \\
5 & -10.8734 \\
6 & -10.8714 \\
7 & -10.3518 \\
8 & -10.3511 \\
9 & -9.3645 \\
10 & -8.3562 \\
11 & -3.0704 \\
12 & -0.9393 \\
13 & 2.1953 \\
\hline
\end{tabular}




\section{Dynamic light scattering}

In order to investigate the volume changes of CAT with various concentrations of BPS, dynamic light scattering was employed in this study. Fig. S9 (A and B) presented the number-size-distribution and the volume-size-distribution of CAT (PDI $=0.35 \sim 0.42$ ), respectively. The hydrodynamic size of CAT without BPS exhibited a major peak at approximately $17 \mathrm{~nm}$ indicating a slightly agglomeration in the CAT molecules. The propensity towards agglomeration could be easily clarified by the negative charge on the surface of CAT molecule whose isoelectric point was 5.4. In Fig. S9, the hydrodynamic size of CAT decreased with the addition of BPS, indicating the existence of the disaggregation of the polymers and the decrease of the size of CAT molecules. This was consistent with the results of three-dimensional spectra study and the resonance light scattering (RLS) study showed in Fig. S8.
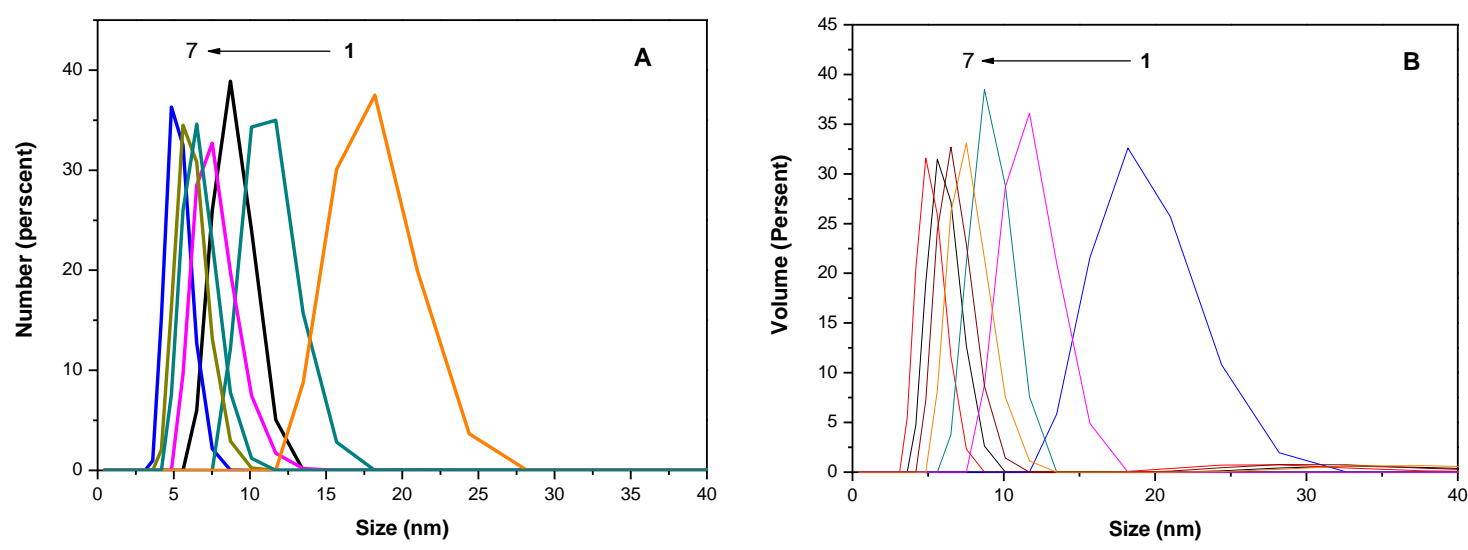

Fig. S9 The dynamic light scattering results of CAT.

Conditions: $\mathrm{C}_{\mathrm{CAT}}: 2 \mu \mathrm{M}, \mathrm{C}_{\mathrm{BPS}}: 0,0.005,0.025,0.1,0.3,0.7,1 \mathrm{mM}, \mathrm{pH}=7.4, \mathrm{~T}=$ 300K. A: number-size-distribution of CAT-BPS system. B: volume-size-distribution of CAT-BPS system 
ROS level of hepatocytes and renal cells after $12 \mathrm{~h}$ incubation with BPS. Cells were exposed to $\mathrm{BPS}$ for $12 \mathrm{~h}$. $\mathrm{C}_{\mathrm{BPS}}(1-6): 0,0.0001,0.001,0.01,0.1,1 \mu \mathrm{M}$

Liver

Kidney
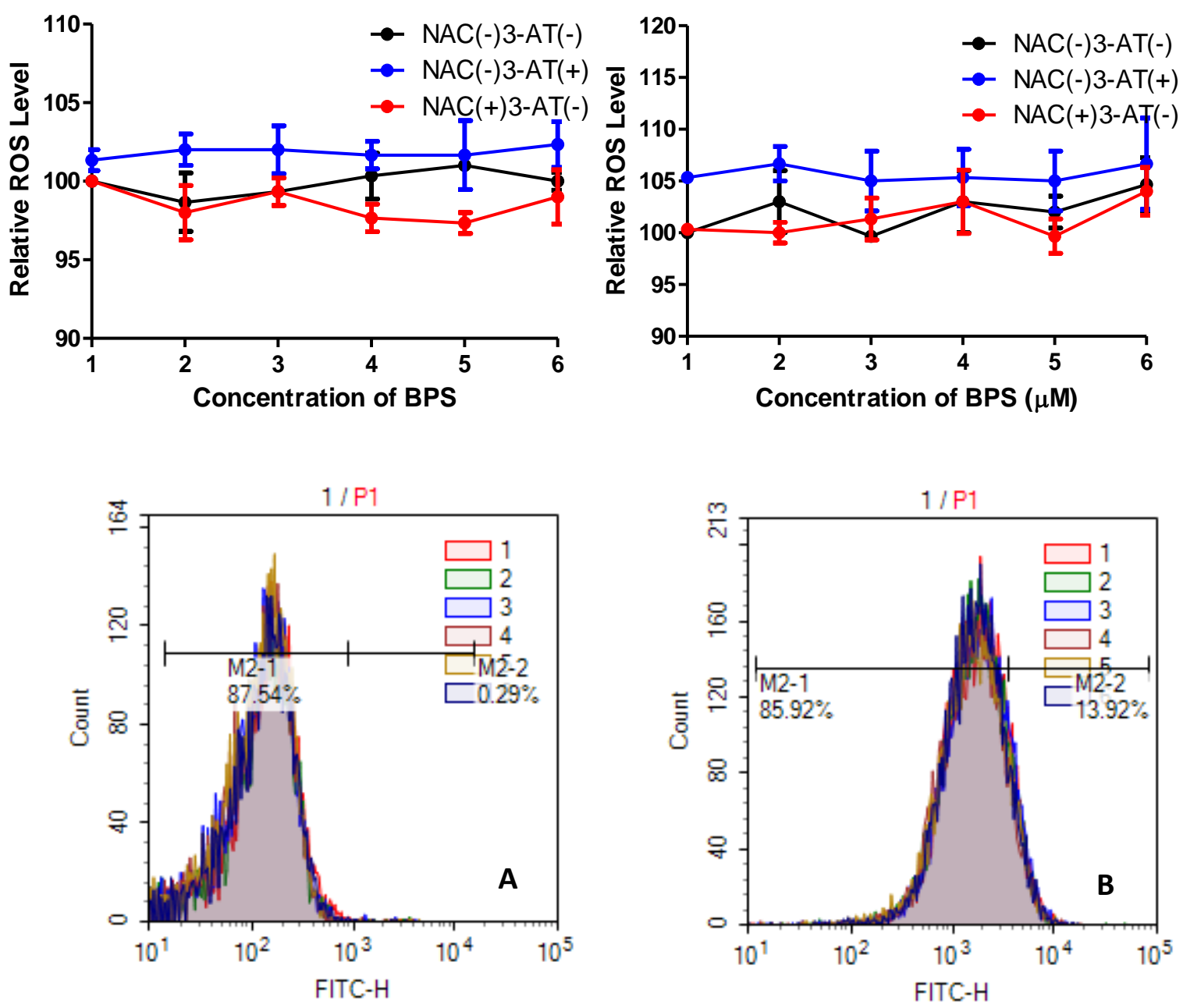
Percentage of apoptotic cells of hepatocytes and renal cells after $12 \mathrm{~h}$ incubation with BPS. $\mathrm{C}_{\mathrm{BPS}}(1-6): 0,0.0001,0.001,0.01,0.1,1 \mu \mathrm{M}$
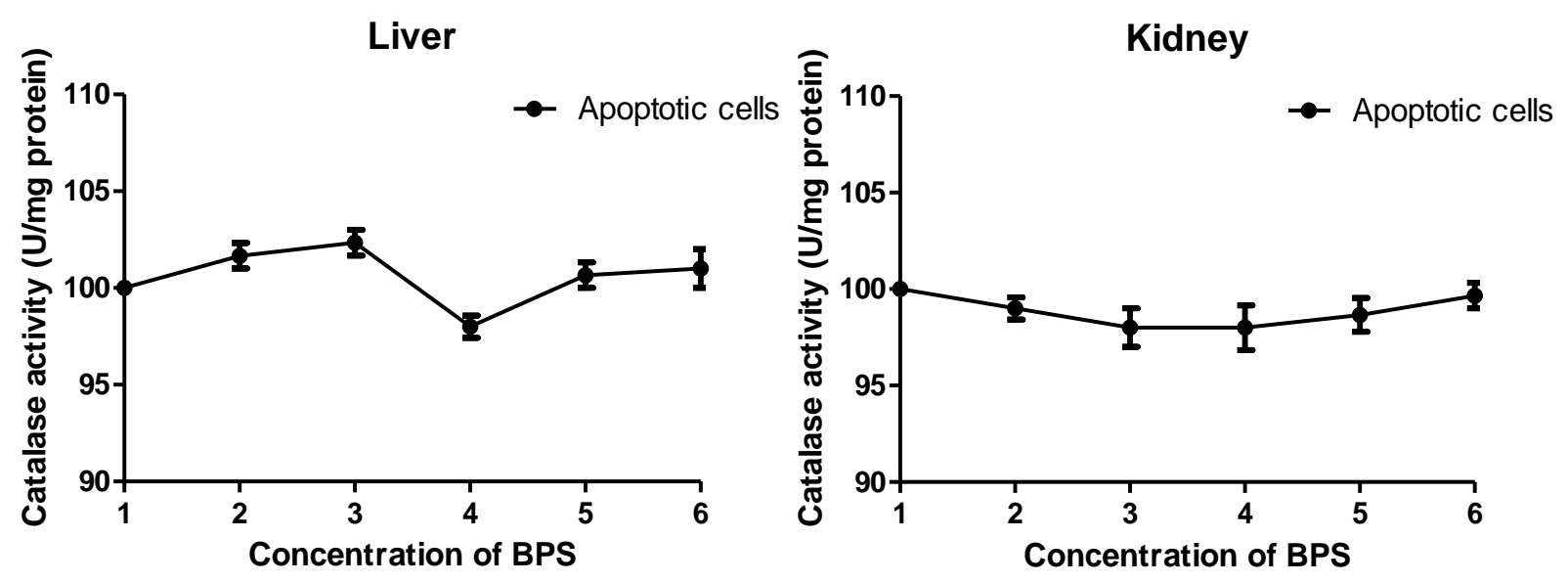